\title{
Cytokines in chronic respiratory diseases
}

\section{Sergei P. Atamas ${ }^{1,2,5}$, Svetlana P. Chapoval ${ }^{2,3}$ and Achsah D. Keegan ${ }^{2,4 *}$}

\author{
Addresses: ${ }^{1}$ Department of Medicine, ${ }^{2}$ Department of Microbiology and Immunology, ${ }^{3}$ Department of Biochemistry and Molecular Biology, and \\ ${ }^{4}$ Center for Vascular and Inflammatory Diseases, University of Maryland School of Medicine, Baltimore, MD 21201, USA; ${ }^{5}$ Baltimore VA Medical \\ Center, Baltimore, MD 21201, USA \\ *Corresponding author: Achsah D. Keegan (akeegan@som.umaryland.edu) \\ FI000 Biology Reports 2013, 5:3 (doi:I0.3410/B5-3) \\ This is an open-access article distributed under the terms of the Creative Commons Attribution-Non Commercial License \\ (http://creativecommons.org/licenses/by-nc/3.0/legalcode), which permits unrestricted use, distribution, and reproduction in any medium, \\ provided the original work is properly cited. You may not use this work for commercial purposes. \\ The electronic version of this article is the complete one and can be found at: http://f1000.com/prime/reports/b/5/3
}

\begin{abstract}
Cytokines are small, secreted proteins that control immune responses. Within the lung, they can control host responses to injuries or infection, resulting in clearance of the insult, repair of lung tissue, and return to homeostasis. Problems can arise when this response is over exuberant and/or cytokine production becomes dysregulated. In such cases, chronic and repeated inflammatory reactions and cytokine production can be established, leading to airway remodeling and fibrosis with unintended, maladaptive consequences. In this report, we describe the cytokines and molecular mechanisms behind the pathology observed in three major chronic diseases of the lung: asthma, chronic obstructive pulmonary disease (COPD), and pulmonary fibrosis. Overlapping mechanisms are presented as potential sites for therapeutic intervention.
\end{abstract}

\section{Introduction}

The healthy balance of normal processes in the lungs, termed pulmonary homeostasis, can be disturbed by external environmental insults or endogenous factors produced during other diseases. In response to insults, the lung responds with an ancient protective mechanism, inflammation. The subsequent course of events depends on the severity of the injury and on the effectiveness of the inflammatory response (Figure 1). If the injury is mild, structural damage to the lung is limited and the lung tissue will rapidly return to homeostasis (Figure 1a). If the injury is more profound and the structural integrity of the tissue and/or vitality of cells are impaired, then the defect in the tissue will be "patched" with newly formed connective tissue - scar. This repair process substitutes functional components of the tissue with extracellular matrix, which fills the defect and, in most cases, allows for the return to tissue homeostasis (Figure 1b). However, problems arise when the injury is severe or repetitive, and the inflammatory and repair processes fail to limit themselves. Under these circumstances, chronic inflammation and exaggerated repair can ensue, in some cases leading to excessive accumulation of extracellular matrix, or so-called pulmonary fibrosis (Figure 1c). In this brief report, we present the regulation of these processes by key cytokines in three representative chronic diseases of the lung - asthma, COPD, and pulmonary fibrosis.

Cytokines are small, secreted regulatory proteins that play critical roles in immune responses. Cytokines participate in cell-cell communication and regulate many functions including cell survival, cell growth, and induction of gene expression. Cytokines can be produced by many cell types. During the adaptive immune response, CD4+ "Helper T-cells" (TH) produce high levels of cytokines with differing functions. These helper cells can become TH1 cells making high levels of interferon (IFN) $\gamma$, TH2 cells making high levels of interleukin (IL)-4, IL-5, and IL-13, or TH17 cells making high levels of IL-17 [1]. These cytokines participate differently in asthma, COPD, and pulmonary fibrosis. While each disease has unique attributes, several cytokines play roles in all three diseases and, thus, may provide interesting targets for therapeutic intervention. 
Figure I. Response of the lung tissue to injury varies depending on the nature of the insult and appropriateness of inflammation and repair

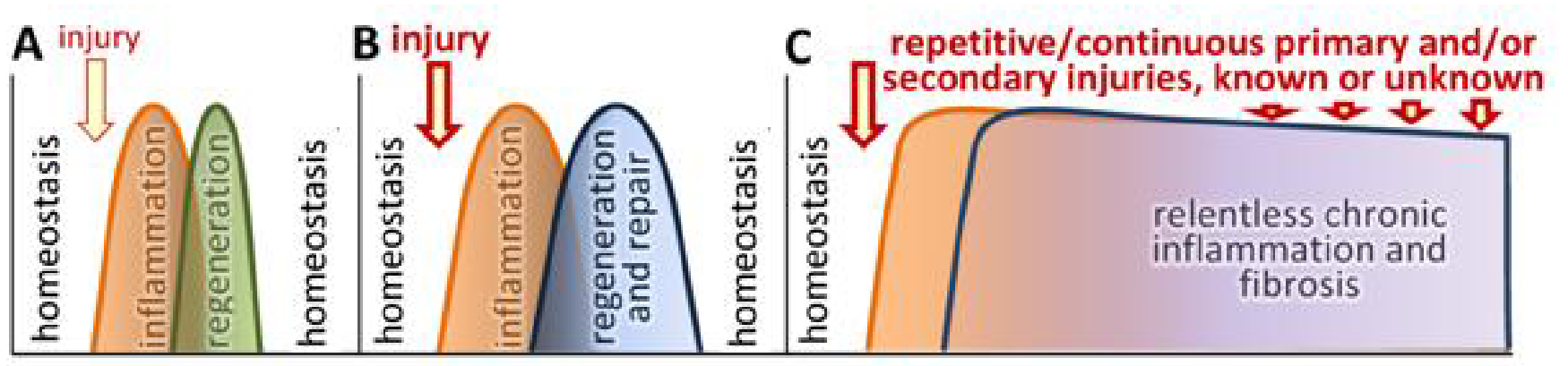

(a) If the injury is mild and structural damage to the tissue is minimal, the process of regeneration allows for a rapid return to homeostasis. (b) A more profound injury affecting the structural integrity of the tissue and vitality of cells leads to repair with deposition of scar tissue, but in most cases there is a return to homeostasis. (c) Repetitive injury, primary or secondary, combined with disturbed tissue responses may lead to continuous inflammation and exaggerated repair, resulting in fibrosis. Note the central involvement of inflammation in all cases, as a bridge between the immediate response to injury and the subsequent repair processes. Although there is a certain overall directionality of the sequence of events from injury to inflammation and to repair, these processes often occur simultaneously at a given time, as indicated by the overlapping corresponding curves.

\section{Asthma}

Asthma is a chronic disease of the lung characterized by shortness of breath, wheeze, cough, reduced airflow on expiration, and airway hyperreactivity to non-specific bronchoconstrictors [2]. Recent evidence suggests that asthma is not a single disease, but consists of several subtypes, including allergic and steroid-resistant asthma $[3,4]$. Allergic asthma is mediated by the TH2 cytokines IL-4, IL-5, and IL-13 (Table 1) [5]. IL-4 participates in the differentiation of naïve $\mathrm{CD} 4+\mathrm{T}$ cells into the TH2 type and is important for the production of allergen-specific IgE [1]. Furthermore, IL-4 drives the alternative activation of macrophages, which have been shown to increase lung inflammation in mouse models of allergic lung inflammation and to be correlated with asthma severity in asthma patients [6-12]. The role of IL-4 in driving allergic asthma is well known, and recent data suggest that its alternatively spliced variant missing exon 2-encoded region, IL-4 $\delta 2$, is naturally produced by cells from patients with asthma but not from healthy controls [13]. This splice variant is active independently of wild-type IL-4 and promotes pulmonary inflammation without $\mathrm{TH} 2$ skewing $[14,15]$.

Like IL-4, IL-13 can also regulate IgE production and the alternative activation of macrophages because it shares a receptor complex and downstream signaling pathways with IL-4 [16]. Furthermore, IL-13 has a distinct and prominent role in mediating the structural changes observed in the airways by modulating goblet cell differentiation and mucus production, airway smooth muscle cell proliferation, and subepithelial fibrosis $[5,17,18]$. Such
Table I. Major cytokines involved in pathogeneses of asthma, COPD, and pulmonary fibrosis

\begin{tabular}{lll}
\hline Asthma & COPD & Pulmonary Fibrosis \\
\hline IL-4, IL-5, IL-I3 & TNF- $\alpha$, IL-I, & TGF- $\beta$, CTGF \\
IL-25, IL-33, TSLP & IL-6, IL-8, IL-I8, IL-32 & IL-4, IL-I3 \\
IL-17 & IL-I7 & MCP-I, Oncostatin M \\
TNF- $\alpha$, IL-I, IL-8, IL-I8 & TSLP & PDGF, GM-CSF \\
RANTES, eotaxin & TGF- $\beta$ & CCLI7, PARC/CCLI8 \\
GM-CSF, VEGF & & SDF-I/CXCLI2 \\
& & IL-I, IL-I7, IL-10 \\
\hline
\end{tabular}

The relative importance of these cytokines is difficult to assess quantitatively; instead, the authors established this order based on their expertise and available literature in the field.

Abbreviations: CCLI7, thymus and activation-regulated chemokine (also known as TARC); COPD, chronic, obstructive pulmonary disease; CTGF, connective tissue growth factor; GM-CSF, granulocyte-macrophage colony-stimulating factor; IL, interleukin; MCP-I, monocyte chemotactic protein (also known as CCL2); PARC, pulmonary and activation-regulated chemokine (also known as CCLI8); PDGF, platelet-derived growth factor; RANTES, regulated and normal T cell expressed and secreted; SDF-I/CXCLI2, stromal cell-derived factor-I; TGF- $\beta$, transforming growth factor beta; TNF- $\alpha$, tumor necrosis factor alpha; TSLP, thymic stromal lymphopoietin; VEGF, vascular endothelial growth factor.

changes lead to airway constriction and hyppereactivity to stimulants, and, after prolonged chronic allergen exposure, tissue remodeling and fibrosis.

IL-5 plays an important role in eosinophilic inflammation during allergic asthma. Studies in both mouse models and human asthmatics have demonstrated that IL-5 is critical for the differentiation of eosinophils from bone marrow precursors and for their trafficking from the bone-marrow 
to the lung [19-24]. Furthermore, IL-5 enhances eosinophil survival [25]. Thus, the TH2 cytokines IL-4, IL-13, and IL-5 orchestrate the set of physiological responses characteristic of allergic asthma including inflammation, airway hyperactivity, and airway remodeling.

In addition to the classic TH2-cell derived cytokines, cytokines produced by airway epithelial cells have recently been recognized as critical mediators of allergic asthma [26,27]. Airway epithelial cells are the first to encounter inhaled allergens or other agents and are stimulated to secrete IL-25 [28], IL-33 [29], and thymic stromal lymphopoietin (TSLP) [30-33]. IL-25 is produced by airway epithelial cells upon exposure to allergens, particles, and helminths [28,34,35]. IL-33 is present in cells in both full-length and mature forms, of which mature IL-33 is a powerful activator of the TH2 responses [29,36-41], whereas full length IL-33 activates inflammation without engaging the IL-33 receptor component T1/ST2 or engaging the TH2 mechanisms [36]. The IL-33 receptor is critical for development of asthma [42-44]. Both IL-25 and IL-33 stimulate the rapid production of IL-5 and IL-13 by natural helper cells (multipotent progenitor cells, nuocytes, c-Kit+Sca-1+ IL-7R+IL-33R+IL-17RB+ cells) in the airways, which promotes $\mathrm{TH} 2$ generation and increases local TH2 cytokine production [45-49]. TSLP primes, polarizes, and maintains TH2 cells [50], and its expression in the airways of patients with asthma has been shown to correlate with disease severity [51-53]. All these TH2associated cytokines are engaged in an intricate interplay with other cytokines including, but not limited to, TNF- $\alpha$ [54-56], IL-1 [57,58], granulocyte-macrophage colonystimulating factor (GM-CSF) $[57,59,60]$, vascular endothelial growth factor (VEGF) [61-64], IL-18 [65,66], and IL-17 [67-73]. Based on studies in mouse models, it is believed that TH17 cells and, therefore, IL-17 cytokines play a role in asthma severity by increasing neutrophil recruitment to the airways [74]. Furthermore, the TH17mediated pathway may contribute to steroid resistance in human asthma, but this has not yet been clearly established [4]. Thus, IL-17-driven asthma may be distinct from allergic asthma and require different therapeutic strategies $[3,4]$. The chemotactic family of cytokines called chemokines also centrally contributes to pathogenesis of asthma by recruiting specific inflammatory cells into the lung tissue [75-77], including regulated and normal T cell expressed and secreted (RANTES)/ chemokine (c-c motif) ligand (CCL)5 [78-81], eotaxins CCL11, CCL24, and CCL26 [81-84], CXCL8/IL-8 [85,86]. While the TH1 cytokine IFN- $\gamma$ is typically thought to suppress TH2mediated responses, several reports indicate that, in certain circumstances, IFN- $\gamma$ is also involved in promoting disease pathogenesis [87-89].

\section{COPD}

COPD is caused by smoking or other prolonged significant exposure to fumes, dust, or polluted air, which causes chronic inflammation of bronchi, destruction of lung tissue (emphysema), and some degree of scarring. The inflammatory process involving $\mathrm{T}$ cells, neutrophils, and macrophages is driven by the classical proinflammatory cytokines TNF- $\alpha[90,91]$, IFN- $\gamma$ [92-94], IL-1 [95], IL-6 [96], IL-8 [90,91,97-102], IL-18 $[92,103,104]$, and IL-32 [105]. Recent evidence also implicates IL-17 in the pathogenesis of COPD [56,92,106-109]. Increased sputum IL-17 levels were identified in COPD patients, and were even more pronounced than those detected in patients with asthma [56]. These levels correlated with a decrease in lung function as measured by a decrease in forced expiratory volume, suggesting a potential role for IL-17 in COPD pathogenesis and defining it as a prognostic target for disease immunotherapy [56]. Although COPD is not considered a TH2 disease, activated TH1 and TH2 cells are found in COPD patients, suggesting that both may contribute to the disease processes. For example, the proTH2 cytokine TSLP is expressed and functionally active not only in patients with asthma but also in patients with COPD $[33,73]$. Similarly, IL-13 may be contributing to mucus metaplasia, airway fibrosis, and vascular remodeling in COPD [92].

Expression of the profibrotic cytokine transforming growth factor (TGF)- $\beta$ is enhanced in the airways of patients with COPD [110-113]. This appears somewhat counterintuitive because TGF- $\beta$ is a potent inducer of connective tissue deposition, whereas COPD is characterized predominantly by lung tissue destruction. Nevertheless, pulmonary fibroblasts from these patients respond to stimulation by TGF- $\beta$ with an enhanced activation of the WNT/ $\beta$-catenin pathway [114], whereas COPD airway smooth muscles respond to similar stimulation with an enhanced deposition of the proteoglycan perlecan [115], suggesting that TGF- $\beta$ contributes to architectural changes in the lungs in COPD. Indeed, peribronchial fibrosis does develop in the lungs of patients with COPD, which is in contrast to mostly subepithelial fibrosis in asthma (see above) and interstitial fibrosis in idiopathic pulmonary fibrosis and scleroderma lung disease (see below).

\section{Pulmonary fibrosis}

Pulmonary fibrosis - excessive accumulation of scar tissue - develops during the progression of a variety of lung diseases. This process may be self-limiting, but in some cases, the fibrotic process becomes overt and irreversible, leading to a significant decline in lung function, the ability to exchange gas. Pulmonary fibrosis 
is the main cause of death in the autoimmune disease scleroderma [116], whereas in patients with idiopathic pulmonary fibrosis, median survival is only two to three years [117]. In cases of such profound pulmonary fibrosis, the available therapies have limited effectiveness. Extracellular matrix, including collagen, accumulates in the lungs through several mechanisms. Resident pulmonary fibroblasts become activated, increase their proliferation rate, while decreasing sensitivity to apoptotic signals, and deposit more extracellular matrix, while slowing down extracellular matrix turnover. Bone marrow-derived cells called fibrocytes home to the lung and differentiate into activated fibroblasts [118-120]. Epithelial-mesenchymal transition, a process by which lung epithelial cells transform into myofibroblasts, also contributes to lung fibrosis [121-123]. All these mechanisms are controlled by cytokines, either through direct recruitment and activation of extracellular matrix-producing cells, or indirectly, through regulation of pulmonary inflammation [124-130], redox balance [131-133], and activity of several enzymatic systems, including matrix metalloproteinases and their inhibitors [130,134-136], and clotting enzymes [126,137-141].

TGF- $\beta$ is undoubtedly the most potent profibrotic cytokine $[142,143]$. It is produced in latent form and normally stored as such in tissues in association with extracellular matrix and needs to be activated to exert its functional effect. Thus, TGF- $\beta$-driven fibrosis is controlled by the mechanisms of its activation rather than production. In the lungs, activation of TGF- $\beta$ by $\alpha \mathrm{V}$ containing integrins plays a central role in the mechanism of fibrosis [127,143-146]. Connective tissue growth factor (CTGF) acts in concert with TGF- $\beta$, contributing to fibrosis $[147,148]$. Furthermore, the TH2 cytokines IL-4 and IL-13 are direct activators of fibrosis [149-154], whereas the TH1 cytokine IFN- $\gamma$ is a potent direct inhibitor of extracellular matrix deposition $[155,156]$. Interestingly, although the levels of Th2 cytokines are substantially higher in asthma than in fibrotic diseases such as scleroderma or idiopathic pulmonary fibrosis, the severity of fibrosis is higher in the latter diseases. Furthermore, scleroderma lung disease and idiopathic pulmonary fibrosis are characterized by diffuse parenchymal accumulation of extracellular matrix, whereas in asthma, fibrosis is mostly subepithelial. A possible explanation for this paradox is that, in asthma, TH2 cytokines are the predominant drivers of fibrosis, whereas in scleroderma lung disease and idiopathic pulmonary fibrosis, the patients experience a "profibrotic cytokine storm", with elevated levels of all of the cytokines listed in this section. Furthermore, TGF- $\beta$ is a more potent profibrotic cytokine, exerting its effect at much lower concentrations than IL-4 or IL-13.
The chemokine monocyte chemotactic protein (MCP)-1/ CCL2 promotes fibrosis through direct and indirect mechanisms [157-160], as do Oncostatin $M[128,161]$ and platelet derived growth factor (PDGF) [162-164]. An important, predominantly indirect, modulator of fibrosis is the chemokine pulmonary and activation-regulated chemokine (PARC)/CCL18, which is elevated in association with various fibrotic lung diseases, such as scleroderma [165,166], hypersensitivity pneumonitis and idiopathic pulmonary fibrosis [166,167], asthma [168], and sarcoidosis [169]. Although PARC/CCL18 directly activates collagen production in fibroblasts in cell culture [170-173], it exerts its profibrotic action in vivo mostly by recruiting profibrotic $\mathrm{T}$ cells $[127,130,174]$. Another chemokine, stromal cell-derived factor (SDF)-1/ chemokine (C-X-C motif) ligand (CXCL) 12 , contributes to fibrosis by recruiting bone marrowderived progenitors of fibroblasts to the lung [175-177]. Numerous other cytokines may contribute to the mechanism of pulmonary fibrosis, but their exact roles remain either controversial or mechanistically unclear, including IL-1 $\beta$ and IL-17 [178-180], IL-10 [181,182], thymus and activation-regulated chemokine (CCL17) [183], and GM-CSF [184-186]. An extensive discussion of cytokines regulating pulmonary fibrosis can be found in [129,187-189].

\section{Cytokine-targeted immunotherapy}

The important contribution of cytokines to features of the chronic lung diseases presented above suggests potential targets for therapeutic intervention using blocking antibodies or therapeutic proteins. Indeed, a number of clinical trials have been performed or are ongoing for many of the cytokine targets. The emerging anti-cytokine therapies for asthma are primarily directed toward IL-4, IL-5, or IL-13 [190-195]. Early studies targeting IL-4 met with limited success [195], likely because they did not also block IL-13. More recent studies with blocking anti-IL-13 antibodies or with an IL-4 mutant that blocks the actions of both IL- 4 and IL-13 showed greater promise in some, but not all, studies [191193,195-197]. The varied effectiveness of IL-13-directed therapies is not surprising considering that only $50 \%$ of asthmatics show elevated levels of sputum IL-13 [198]. Similarly, there are controversial results on the effectiveness of IL-5 directed therapies [196,197]. While anti-IL-5 antibody was effective at reducing eosinophil numbers in blood and sputum, it was substantially less effective at reducing eosinophil numbers in the lung and had a modest impact on lung function [194]. Therefore, it is clear that currently existing therapies have to be extended to include downregulation of additional pathways that have been shown to play roles in asthma pathogenesis such as TSLP, IL-17, IL-25, IL-33 [199]. Other more 
"non-traditional" molecular pathways might also prove to be effective targets. As an example, we recently have shown that neuroimmune semaphorin $4 \mathrm{~A}$ plays a downregulatory role in experimental asthma severity, in part, by regulation of IL-13 [200,201].

Targets for COPD and lung fibrosis are less numerous. Several drugs targeting the tumor necrosis factor (TNF)- $\alpha$ pathway have been developed and used in clinical settings. Some of them (i.e. mouse/human IgG1 antibody against TNF- $\beta$, ifliximab) were found to be effective in asthma but not in COPD [202-205]. A soluble human TNFR2, etanercept, reduced lung pathophysiology in patients with severe forms of disease $[54,55]$. Clinical studies of a fully humanized IL-1 $\beta$ blocking antibody (canakinumab) and anti-IL-6R blocking antibody (tocilizumab) were reported to be in progress in patients with COPD and rheumatoid arthritis, correspondingly [206], but no final results have been revealed yet. Several drugs have been developed to target the VEGF pathway, which has been implicated in asthma, such as bevacizumab, VEGF-Trap, and PTK737 [207] with clinical trials being limited thus far to cancer, ischemia, and age-related macular degeneration [208]. The identification and targeting of a cytokine active in more than one chronic lung disease would clearly be beneficial.

\section{Summary}

There is growing awareness that there are key similarities in the contribution of cytokines and the manifestation of lung pathology among the chronic respiratory diseases [209]. As noted in Table 1, several of the cytokines contribute to multiple chronic disease states (e.g. TGF- $\beta$, IL-17, TSLP, IL-4, IL-13). While we have learned much about the general role of cytokines in these diseases, many questions remain unanswered. What is the relationship between the major chronic respiratory diseases? Are there common targets for intervention? Will it be possible in the future to attenuate or even abrogate the undesired excessive responses by therapeutically targeting cytokines? Experiments in animals have been very promising, but their translation into clinical trials lags behind. One difficulty is that cytokines are functionally pleiotropic and redundant, and, as a result, targeting an individual cytokine may have a less than expected effect (due to functional substitution by other, functionally similar, cytokines) or have undesired side effects (due to pleiotropy). Another difficulty is that mouse models do not completely mimic the disease in humans [210-212]. It will be important to further understand these issues to increase the likelihood that targeting cytokines will improve the clinical outcome for patients with chronic lung diseases.

\section{Abbreviations}

$\mathrm{CCL}$, chemokine (C-C motif) ligand; COPD, chronic, obstructive pulmonary disease; CTGF, connective tissue growth factor; $\mathrm{CXCL}$, chemokine (C-X-C motif) ligand; GM-CSF, granulocyte-macrophage colony-stimulating factor; IFN, interferon; IL, interleukin; MCP-1, monocyte chemotactic protein; PARC, pulmonary and activationregulated chemokine; PDGF, platelet-derived growth factor; RANTES, regulated and normal $\mathrm{T}$ cell expressed and secreted; SDF-1, stromal cell-derived factor- 1 ; TGF- $\beta$, transforming growth factor beta; TH, T helper cells; TNF, tumor necrosis factor; TSLP, thymic stromal lymphopoietin; VEGF, vascular endothelial growth factor.

\section{Disclosures}

The authors declare that they have no disclosures.

\section{Acknowledgements}

We thank the members of our laboratories for valuable discussions and insight. This work was supported by NIH grants AI038985 (ADK), HL106196 (SAP), and AI076736 (SPC) and the VA Merit Award 5I01CX00010 (SAP).

\section{References}

I. Zhu J, Paul WE: CD4 T cells: fates, functions, and faults. Blood 2008, I I 2: I557-69.

2. Busse WW, Rosenwasser LJ: Mechanisms of asthma. The Journal of allergy and clinical immunology 2003, I I I:S799-804.

3. Bhakta NR, Woodruff PG: Human asthma phenotypes: from the clinic, to cytokines, and back again. Immunol Rev 20I I, 242: 220-32.

4. Wenzel SE: Asthma phenotypes: the evolution from clinical to molecular approaches. Nature medicine 20I2, I8:716-25.

\section{FlOOOPrime}

\section{RECOMMENDED}

5. Wills-Karp M: Interleukin-I3 in asthma pathogenesis. Immunol Rev 2004, 202: I75-90.

6. Lee CG, Hartl D, Lee GR, Koller B, Matsuura H, Da Silva CA, Sohn MH, Cohn L, Homer RJ, Kozhich AA, Humbles A, Kearley J, Coyle A, Chupp G, Reed J, Flavell RA, Elias JA: Role of breast regression protein 39 (BRP-39)/chitinase 3-like-I in Th2 and IL-I3-induced tissue responses and apoptosis. The Journal of experimental medicine 2009, 206: I |49-66.

7. Kim EY, Battaile JT, Patel AC, You Y, Agapov E, Grayson MH, Benoit LA, Byers DE, Alevy Y, Tucker J, Swanson S, Tidwell R, Tyner JW, Morton JD, Castro M, Polineni D, Patterson GA, Schwendener RA, Allard JD, Peltz G, Holtzman MJ: Persistent activation of an innate immune response translates respiratory viral infection into chronic lung disease. Nature medicine 2008, 14:633-40.

FlOOOPrime

RECOMMENDED

8. Melgert BN, Oriss TB, Qi Z, Dixon-McCarthy B, Geerlings M, Hylkema MN, Ray A: Macrophages: regulators of sex differences in asthma? American journal of respiratory cell and molecular biology 2010, 42:595-603.

9. Melgert BN, ten Hacken NH, Rutgers B, Timens W, Postma DS, Hylkema MN: More alternative activation of macrophages in lungs of asthmatic patients. The Journal of allergy and clinical immunology 201 I, 1 27:831-3.

10. Subrata LS, Bizzintino J, Mamessier E, Bosco A, McKenna KL, Wikstrom ME, Goldblatt J, Sly PD, Hales BJ, Thomas WR, Laing IA, LeSouëf PN, Holt PG: Interactions between innate antiviral 
and atopic immunoinflammatory pathways precipitate and sustain asthma exacerbations in children. J Immunol 2009, I83: 2793-800

II. Ford AQ, Dasgupta P, Mikhailenko I, Smith EM, Noben-Trauth N, Keegan AD: Adoptive transfer of IL-4Ralpha(+) macrophages is sufficient to enhance eosinophilic inflammation in a mouse model of allergic lung inflammation. BMC Immunol 20 I 2, I 3:6.

12. Dasgupta $P$, Keegan AD: Contribution of Alternatively Activated Macrophages to Allergic Lung Inflammation: A Tale of Mice and Men. J Innate Immun 2012, 4:478-88.

13. Luzina IG, Lockatell V, Lavania S, Pickering EM, Kang PH, Bashkatova YN, Andreev SM, Atamas SP: Natural production and functional effects of alternatively spliced interleukin-4 protein in asthma. Cytokine 2012, 58:20-6.

14. Luzina IG, Lockatell V, Todd NW, Highsmith K, Keegan AD, Hasday JD, Atamas SP: Alternatively spliced variants of interleukin-4 promote inflammation differentially. I Leukoc Biol 201I, 89: 763-70.

\section{FIOOOPrime}

15. Luzina IG, Lockatell V, Todd NW, Keegan AD, Hasday JD, Atamas SP: Splice isoforms of human interleukin-4 are functionally active in mice in vivo. Immunology 201 I, I32:385-93.

16. Heller NM, Dasgupta P, Dorsey NJ, Chapoval SP, Keegan AD: The type I and type II receptor complexes for IL-4 and IL-I3 differentially regulate allergic lung inflammation. In Allergic Diseases - Highlights in the Clinic, Mechanisms and Treatment. Edited by Pereira C. Rijeca, Croatia: InTECH; 2012: 43-82.

17. Munitz A, Brandt EB, Mingler M, Finkelman FD, Rothenberg ME: Distinct roles for IL- I 3 and IL-4 via IL- I 3 receptor alpha I and the type II IL-4 receptor in asthma pathogenesis. Proc Natl Acad Sci U S A 2008, 105:7240-5.

\section{FIOOOPRIM
RECOMMENDED}

18. Ramalingam TR, Pesce JT, Sheikh F, Cheever AW, Mentink-Kane MM, Wilson MS, Stevens S, Valenzuela DM, Murphy AJ, Yancopoulos GD, Urban JF Jr, Donnelly RP, Wynn TA: Unique functions of the type II interleukin 4 receptor identified in mice lacking the interleukin I 3 receptor alpha I chain. Nat Immunol 2008, 9:25-33.

\section{FlOOOPrime}

RECOMMENDED

19. Lopez AF, Sanderson C], Gamble JR, Campbell HD, Young IG, Vadas MA: Recombinant human interleukin 5 is a selective activator of human eosinophil function. The Journal of experimental medicine 1988, 167:219-24.

\section{FlOOOPrime}

\section{RECOMMENDED}

20. Foster PS, Hogan SP, Ramsay AJ, Matthaei KI, Young IG: Interleukin 5 deficiency abolishes eosinophilia, airways hyperreactivity, and lung damage in a mouse asthma model. The Journal of experimental medicine 1996, I83:195-201.

\section{FIOOOPrime \\ RECOMMENDED}

21. Lee J], McGarry MP, Farmer SC, Denzler KL, Larson KA, Carrigan PE, Brenneise IE, Horton MA, Haczku A, Gelfand EW, Leikauf GD, Lee NA: Interleukin-5 expression in the lung epithelium of transgenic mice leads to pulmonary changes pathognomonic of asthma. The Journal of experimental medicine 1997, I85: 2143-56.

22. Hamelmann E, Oshiba A, Loader J, Larsen GL, Gleich G, Lee J, Gelfand EW: Antiinterleukin-5 antibody prevents airway hyperresponsiveness in a murine model of airway sensitization. American journal of respiratory and critical care medicine 1997, 155:819-25

23. Sur S, Gleich GJ, Swanson MC, Bartemes KR, Broide DH: Eosinophilic inflammation is associated with elevation of interleukin-5 in the airways of patients with spontaneous symptomatic asthma. The Journal of allergy and clinical immunology 1995, 96:66 I-8.

24. Leckie MJ, ten Brinke A, Khan J, Diamant Z, O'Connor BJ, Walls CM, Mathur AK, Cowley HC, Chung KF, Djukanovic R, Hansel TT,
Holgate ST, Sterk PJ, Barnes PJ: Effects of an interleukin-5 blocking monoclonal antibody on eosinophils, airway hyperresponsiveness, and the late asthmatic response. Lancet 2000 , 356:2144-8.

\section{FIOOOPrime}

25. Stirling RG, van Rensen EL, Barnes PJ, Chung KF: Interleukin-5 induces CD34(+) eosinophil progenitor mobilization and eosinophil CCR3 expression in asthma. American journal of respiratory and critical care medicine 200 I, 164:1403-9.

\section{FlOOOPrime
RECOMMENDED}

26. Lambrecht $\mathrm{BN}$, Hammad $\mathrm{H}$ : Biology of lung dendritic cells at the origin of asthma. Immunity 2009, 3 I:4 I 2-24.

27. Kool M, Hammad H, Lambrecht BN: Cellular networks controlling Th2 polarization in allergy and immunity. Fl000 Biol Rep 20I2, 4:6.

\section{FlOOOPrime
RECOMMENDED}

28. Angkasekwinai P, Park H, Wang YH, Chang SH, Corry DB, Liu YJ, Zhu Z, Dong C: Interleukin 25 promotes the initiation of proallergic type 2 responses. The Journal of experimental medicine 2007, 204:I509-I7.

\section{FlOOOPrime
RECOMMENDED}

29. Schmitz J, Owyang A, Oldham E, Song Y, Murphy E, McClanahan TK, Zurawski G, Moshrefi M, Qin J, Li X, Gorman DM, Bazan JF, Kastelein RA: IL-33, an interleukin-I-like cytokine that signals via the IL-I receptor-related protein ST2 and induces T helper type 2-associated cytokines. Immunity 2005, 23:479-90.

\section{FlOOOPrime}

RECOMMENDED

30. Iseki M, Omori-Miyake $M, X u$ W, Sun X, Takaki S, Rawlings D Ziegler SF: Thymic stromal lymphopoietin (TSLP)-induced polyclonal B-cell activation and autoimmunity are mediated by CD4+ T cells and IL-4. Int Immunol 20I2, 24:I83-95.

31. Okayama Y, Okumura S, Sagara H, Yuki K, Sasaki T, Watanabe N Fueki M, Sugiyama K, Takeda K, Fukuda T, Saito H, Ra C: FcepsilonRI-mediated thymic stromal lymphopoietin production by interleukin-4-primed human mast cells. Eur Respir J 2009, 34:425-35.

32. Omori M, Ziegler S: Induction of IL-4 expression in CD4(+) T cells by thymic stromal Iymphopoietin. I Immunol 2007, I 78: | 396-404.

33. Ying S, O'Connor B, Ratoff J, Meng Q, Fang C, Cousins D, Zhang G, Gu S, Gao Z, Shamji B, Edwards MJ, Lee TH, Corrigan CJ: Expression and cellular provenance of thymic stromal lymphopoietin and chemokines in patients with severe asthma and chronic obstructive pulmonary disease. J Immunol 2008 , | 8 | :2790-8.

\section{FlOOOPrime}

\section{RECOMMENDED}

34. Hurst SD, Muchamuel T, Gorman DM, Gilbert IM, Clifford T, Kwan S, Menon S, Seymour B, Jackson C, Kung TT, Brieland JK, Zurawski SM, Chapman RW, Zurawski G, Coffman RL: New IL-I 7 family members promote Thl or Th2 responses in the lung: in vivo function of the novel cytokine IL-25. J Immunol 2002, 169: 443-53.

35. Hammad $H$, Chieppa M, Perros F, Willart MA, Germain RN, Lambrecht BN: House dust mite allergen induces asthma via Toll-like receptor 4 triggering of airway structural cells. Nature medicine 2009, I5:410-6.

\section{FlOOOPrime \\ RECOMMENDED}

36. Luzina IG, Pickering EM, Kopach P, Kang PH, Lockatell V, Todd NW, Papadimitriou JC, McKenzie AN, Atamas SP: Full-Length IL-33 Promotes Inflammation but not Th2 Response In Vivo in an ST2-Independent Fashion. J Immunol 20I2, I 89:403-I0.
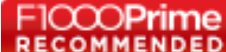
37. Komai-Koma M, Xu D, Li Y, McKenzie AN, Mclnnes IB, Liew FY: IL-33 is a chemoattractant for human Th2 cells. Eur J Immunol 2007, 37:2779-86.

38. Louten J, Rankin AL, Li Y, Murphy EE, Beaumont M, Moon C, Bourne P, McClanahan TK, Pflanz S, de Waal Malefyt R: Endogenous IL-33 enhances Th2 cytokine production and T-cell responses during allergic airway inflammation. Int Immunol 20II, 23:307-15.

39. Lohning M, Stroehmann A, Coyle AJ, Grogan JL, Lin S, GutierrezRamos JC, Levinson D, Radbruch A, Kamradt T: TI/ST2 is preferentially expressed on murine Th2 cells, independent of interleukin 4, interleukin 5, and interleukin 10, and important for Th2 effector function. Proc Natl Acad Sci U S A 1998, 95:6930-5.

40. Nawijn MC, Dingian GM, Ferreira R, Lambrecht BN, Karis A, Grosveld F, Savelkoul H, Hendriks RW: Enforced expression of GATA-3 in transgenic mice inhibits Thl differentiation and induces the formation of a TI/ST2-expressing Th2-committed T cell compartment in vivo. J Immunol 200I, I67:724-32.

4I. Meisel C, Bonhagen K, Lohning M, Coyle AJ, Gutierrez-Ramos IC, Radbruch A, Kamradt T: Regulation and function of TI/ST2 expression on CD4+ $T$ cells: induction of type 2 cytokine production by TI/ST2 cross-linking. J Immunol 200I, 166:3|43-50.

42. Coyle AJ, Lloyd C, Tian J, Nguyen T, Erikkson C, Wang L, Ottoson P, Persson P, Delaney T, Lehar S, Lin S, Poisson L, Meisel C, Kamradt T, Bjerke T, Levinson D, Gutierrez-Ramos JC: Crucial role of the interleukin I receptor family member TI/ST2 in T helper cell type 2-mediated lung mucosal immune responses. The Journal of experimental medicine 1999, 190:895-902.

\section{FlOOOPrime \\ RECOMMENDED}

43. Walzl G, Matthews S, Kendall S, Gutierrez-Ramos JC, Coyle AJ, Openshaw PJ, Hussell T: Inhibition of TI/ST2 during respiratory syncytial virus infection prevents $T$ helper cell type 2 (Th2)but not ThI-driven immunopathology. The Journal of experimental medicine 200I, 193:785-92.

44. Townsend MJ, Fallon PG, Matthews DJ, Jolin HE, McKenzie AN: TI/ST2-deficient mice demonstrate the importance of TI/ST2 in developing primary T helper cell type 2 responses. The Journal of experimental medicine 2000, 191:1069-76.

45. Neill DR, Wong SH, Bellosi A, Flynn RJ, Daly M, Langford TK, Bucks C, Kane CM, Fallon PG, Pannell R, Jolin HE, McKenzie AN: Nuocytes represent a new innate effector leukocyte that mediates type-2 immunity. Nature 2010, 464:1367-70.

\section{FlOOOPrime}

46. Moro K, Yamada T, Tanabe M, Takeuchi T, Ikawa T, Kawamoto H, Furusawa J, Ohtani M, Fujii H, Koyasu S: Innate production of $\mathbf{T}(\mathrm{H}) 2$ cytokines by adipose tissue-associated c-Kit(+)Sca-I (+) lymphoid cells. Nature 2010, 463:540-4.

\section{FlOOOPrime}

\section{RECOMMENDED}

47. Saenz SA, Siracusa MC, Perrigoue JG, Spencer SP, Urban JF Jr., Tocker JE, Budelsky AL, Kleinschek MA, Kastelein RA, Kambayashi T, Bhandoola A, Artis D: IL25 elicits a multipotent progenitor cell population that promotes $\mathrm{T}(\mathrm{H}) 2$ cytokine responses. Nature 2010, 464:1362-6.

FlOOOPrime RECOMMENDED

48. Price AE, Liang HE, Sullivan BM, Reinhardt RL, Eisley CJ, Erle DJ, Locksley RM: Systemically dispersed innate IL-13-expressing cells in type 2 immunity. Proc Natl Acad Sci U S A 2010, 107: | | 489-94.

\section{FlOOOPrime}

49. Barlow JL, Bellosi A, Hardman CS, Drynan LF, Wong SH, Cruickshank JP, McKenzie AN: Innate IL-I3-producing nuocytes arise during allergic lung inflammation and contribute to airways hyperreactivity. The Journal of allergy and clinical immunology 2012, I29:191-8 e191-4.
50. Wang $\mathrm{YH}$, Ito $\mathrm{T}$, Homey B, Watanabe N, Martin R, Barnes C], McIntyre BW, Gilliet M, Kumar R, Yao Z, Liu YJ: Maintenance and polarization of human TH2 central memory $T$ cells by thymic stromal lymphopoietin-activated dendritic cells. Immunity 2006, 24:827-38.

5I. Ying S, O'Connor B, Ratoff J, Meng Q, Mallett K, Cousins D, Robinson D, Zhang G, Zhao J, Lee TH, Corrigan C: Thymic stromal lymphopoietin expression is increased in asthmatic airways and correlates with expression of Th2-attracting chemokines and disease severity. J Immunol 2005, I74:8I83-90.

\section{FlOOOPrime
RECOMMENDED}

52. Al-Shami A, Spolski R, Kelly J, Keane-Myers A, Leonard WJ: A role for TSLP in the development of inflammation in an asthma model. The Journal of experimental medicine 2005, 202:829-39.

\section{FlOOOPYime
RECOMMENDED}

53. Li YL, Li HJ, Ji F, Zhang X, Wang R, Hao JQ, Bi WX, Dong L: Thymic stromal lymphopoietin promotes lung inflammation through activation of dendritic cells. The Journal of asthma: official journal of the Association for the Care of Asthma 2010, 47:1 17-23.

54. Berry MA, Hargadon B, Shelley M, Parker D, Shaw DE, Green RH, Bradding P, Brightling CE, Wardlaw AJ, Pavord ID: Evidence of a role of tumor necrosis factor alpha in refractory asthma. The New England journal of medicine 2006, 354:697-708.

\section{FIOOOPrime
RECOMMENDED}

55. Howarth PH, Babu KS, Arshad HS, Lau L, Buckley M, McConnell W, Beckett P, Al Ali M, Chauhan A, Wilson S), Reynolds A, Davies DE, Holgate ST: Tumour necrosis factor (TNFalpha) as a novel therapeutic target in symptomatic corticosteroid dependent asthma. Thorax 2005, 60:1012-8.

\section{FlOOOPrime}

\section{RECOMMENDED}

56. Doe C, Bafadhel M, Siddiqui S, Desai D, Mistry V, Rugman P, McCormick M, Woods J, May R, Sleeman MA, Anderson IK, Brightling CE: Expression of the $T$ helper 17-associated cytokines IL-I7A and IL-I7F in asthma and COPD. Chest 2010, 138:1140-7.

\section{FlOOOPrime}

\section{RECOMMENDED}

57. Willart MA, Deswarte K, Pouliot P, Braun H, Beyaert $R$, Lambrecht BN, Hammad H: Interleukin-I alpha controls allergic sensitization to inhaled house dust mite via the epithelial release of GM-CSF and IL-33. The Journal of experimental medicine 2012, 209:1505-17.

FloOOPrime

58. Schmitz N, Kurrer M, Kopf M: The IL-I receptor I is critical for Th2 cell type airway immune responses in a mild but not in a more severe asthma model. Eur J Immunol 2003, 33:99I-1000.

\section{FlOOOPrime
RECOMMENDED}

59. Saha S, Doe C, Mistry V, Siddiqui S, Parker D, Sleeman M, Cohen ES, Brightling CE: Granulocyte-macrophage colony-stimulating factor expression in induced sputum and bronchial mucosa in asthma and COPD. Thorax 2009, 64:67I-6.

60. Yamashita N, Tashimo $H$, Ishida $H$, Kaneko F, Nakano J, Kato H, Hirai K, Horiuchi T, Ohta K: Attenuation of airway hyperresponsiveness in a murine asthma model by neutralization of granulocyte-macrophage colony-stimulating factor (GM-CSF). Cell Immunol 2002, 219:92-7.

\section{FlOOOPrime}

\section{RECOMMENDED}

6I. Vrugt B, Wilson S, Bron A, Holgate ST, Djukanovic R, Aalbers R: Bronchial angiogenesis in severe glucocorticoid-dependent asthma. Eur Respir J 2000, I5:1014-21.

62. Hoshino M, Nakamura Y, Hamid QA: Gene expression of vascular endothelial growth factor and its receptors and angiogenesis 
in bronchial asthma. The Journal of allergy and clinical immunology 2001, 107:1034-8.

63. Chapoval SP, Lee CG, Tang C, Keegan AD, Cohn L, Bottomly K, Elias JA: Lung vascular endothelial growth factor expression induces local myeloid dendritic cell activation. Clin Immunol 2009, | 32:37|-84.

64. Lee CG, Link H, Baluk P, Homer RJ, Chapoval S, Bhandari V, Kang MJ, Cohn L, Kim YK, McDonald DM, Elias JA: Vascular endothelial growth factor (VEGF) induces remodeling and enhances TH2-mediated sensitization and inflammation in the lung. Nature medicine 2004, 10:1095-103.

\section{FlOOOPrime}

\section{RECOMMENDED}

65. Harada M, Obara K, Hirota T, Yoshimoto T, Hitomi Y, Sakashita M, Doi S, Miyatake A, Fujita K, Enomoto T, Taniguchi M, Higashi N, Fukutomi Y, Nakanishi K, Nakamura Y, Tamari M: A functional polymorphism in IL- I 8 is associated with severity of bronchial asthma. American journal of respiratory and critical care medicine 2009, I 80: 1048-55

66. Wild JS, Sigounas A, Sur N, Siddiqui MS, Alam R, Kurimoto M, Sur S: IFN-gamma-inducing factor (IL- I8) increases allergic sensitization, serum IgE, Th2 cytokines, and airway eosinophilia in a mouse model of allergic asthma. J Immunol 2000, I64:270I-I0.

67. Bellini A, Marini MA, Bianchetti L, Barczyk M, Schmidt M, Mattoli S: Interleukin (IL)-4, IL-I3, and IL-I7A differentially affect the profibrotic and proinflammatory functions of fibrocytes from asthmatic patients. Mucosal immunology 2012, 5:140-9.

68. Nakajima H, Hirose K: Role of IL-23 and ThI7 Cells in Airway Inflammation in Asthma. Immune network 2010, 10:1-4.

69. Molet S, Hamid Q, Davoine F, Nutku E, Taha R, Page N, Olivenstein R, Elias J, Chakir J: IL-I7 is increased in asthmatic airways and induces human bronchial fibroblasts to produce cytokines. The Journal of allergy and clinical immunology 200I, I08:430-8.

70. Pene J, Chevalier S, Preisser L, Venereau E, Guilleux MH, Ghannam S, Moles JP, Danger Y, Ravon E, Lesaux S, Yssel H, Gascan H: Chronically inflamed human tissues are infiltrated by highly differentiated Th I 7 lymphocytes. J Immunol 2008, 180:7423-30.

7I. Bullens DM, Truyen E, Coteur L, Dilissen E, Hellings PW, Dupont LJ, Ceuppens JL: IL-17 mRNA in sputum of asthmatic patients: linking $\mathbf{T}$ cell driven inflammation and granulocytic influx? Respiratory research 2006, 7:135.

72. Korn T, Bettelli E, Oukka M, Kuchroo VK: IL-I7 and ThI7 Cells. Annual review of immunology 2009, 27:485-5I7.

73. Redhu NS, Gounni AS: Function and mechanisms of TSLP/ TSLPR complex in asthma and COPD. Clin Exp Allergy 2012, 42:994- 1005

74. McKinley L, Alcorn JF, Peterson A, Dupont RB, Kapadia S, Logar A, Henry A, Irvin CG, Piganelli JD, Ray A, Kolls JK: THI 7 cells mediate steroid-resistant airway inflammation and airway hyperresponsiveness in mice. J Immunol 2008, I 8 I:4089-97.

\section{FlOOOPrime}

\section{RECOMMENDED}

75. Palmqvist C, Wardlaw AJ, Bradding P: Chemokines and their receptors as potential targets for the treatment of asthma. Br J Pharmacol 2007, I 5 I(6):725-736.

76. Hartl D, Lee CG, Da Silva CA, Chupp GL, Elias JA: Novel biomarkers in asthma: chemokines and chitinase-like proteins. Curr Opin Allergy Clin Immunol 2009, 9:60-6.

77. Zeng R, Li C, Li N, Wei L, Cui Y: The role of cytokines and chemokines in severe respiratory syncytial virus infection and subsequent asthma. Cytokine 201 I, 53:1-7.

\section{FlOOOPrime} RECOMMENDED

78. Rojas-Ramos E, Avalos AF, Perez-Fernandez L, Cuevas-Schacht F, Valencia-Maqueda E, Teran LM: Role of the chemokines RANTES, monocyte chemotactic proteins-3 and -4 , and eotaxins-I and -2 in childhood asthma. Eur Respir J 2003, 22:310-6.
79. Schuh JM, Blease K, Hogaboam CM: The role of $\mathrm{CC}$ chemokine receptor 5 (CCR5) and RANTES/CCL5 during chronic fungal asthma in mice. FASEB J 2002, 16:228-30

\section{FlOOOPrime}

\section{RECOMMENDED}

80. Alam R, York J, Boyars M, Stafford S, Grant JA, Lee J, Forsythe P, Sim T, Ida N: Increased MCP-I, RANTES, and MIP-Ialpha in bronchoalveolar lavage fluid of allergic asthmatic patients. American journal of respiratory and critical care medicine 1996, I 53:1398-404.

\section{FlOOOPrime \\ RECOMMENDED}

8I. Ying S, Meng Q, Zeibecoglou K, Robinson DS, Macfarlane A, Humbert M, Kay AB: Eosinophil chemotactic chemokines (eotaxin, eotaxin-2, RANTES, monocyte chemoattractant protein-3 (MCP-3), and MCP-4), and C-C chemokine receptor 3 expression in bronchial biopsies from atopic and nonatopic (Intrinsic) asthmatics. J Immunol 1999, I63:632I-9.

82. Ravensberg AJ, Ricciardolo FL, van Schadewijk A, Rabe KF, Sterk PJ, Hiemstra PS, Mauad T: Eotaxin-2 and eotaxin-3 expression is associated with persistent eosinophilic bronchial inflammation in patients with asthma after allergen challenge. The Journal of allergy and clinical immunology 2005, I I 5:779-85.

\section{FlOOOPrime \\ RECOMMENDED}

83. Dent G, Hadjicharalambous C, Yoshikawa T, Handy RL, Powell J, Anderson IK, Louis R, Davies DE, Djukanovic R: Contribution of eotaxin-I to eosinophil chemotactic activity of moderate and severe asthmatic sputum. American journal of respiratory and critical care medicine 2004, 169: I | 10-7.

84. Nakamura $H$, Weiss ST, Israel E, Luster AD, Drazen JM, Lilly CM: Eotaxin and impaired lung function in asthma. American journal of respiratory and critical care medicine 1999, 160:1952-6.

85. Ordonez CL, Shaughnessy TE, Matthay MA, Fahy JV: Increased neutrophil numbers and IL-8 levels in airway secretions in acute severe asthma: Clinical and biologic significance. American journal of respiratory and critical care medicine 2000, | 6 I: 1 | $85-90$

86. John AE, Zhu YM, Brightling CE, Pang L, Knox AJ: Human airway smooth muscle cells from asthmatic individuals have CXCL8 hypersecretion due to increased NF-kappa B p65, C/EBP beta, and RNA polymerase II binding to the CXCL8 promoter. J Immunol 2009, I 83:4682-92.

\section{FlOOOPrime}

87. Cho SH, Stanciu LA, Holgate ST, Johnston SL: Increased interleukin-4, interleukin-5, and interferon-gamma in airway CD4+ and CD8+ $\mathbf{T}$ cells in atopic asthma. American journal of respiratory and critical care medicine 2005, I71:224-30.

88. Brooks GD, Buchta KA, Swenson CA, Gern JE, Busse WW: Rhinovirusinduced interferon-gamma and airway responsiveness in asthma. American journal of respiratory and critical care medicine 2003 , 168: $109 \mid-4$

\section{FlOOOPrime}

\section{RECOMMENDED}

89. Kobayashi M, Ashino S, Shiohama Y, Wakita D, Kitamura H, Nishimura T: IFN-gamma elevates airway hyper-responsiveness via up-regulation of neurokinin A/neurokinin-2 receptor signaling in a severe asthma model. Eur J Immunol 20I2, 42:393-402.

90. Keatings VM, Collins PD, Scott DM, Barnes PJ: Differences in interleukin-8 and tumor necrosis factor-alpha in induced sputum from patients with chronic obstructive pulmonary disease or asthma. American journal of respiratory and critical care medicine 1996, 153:530-4

91. Aaron SD, Angel JB, Lunau M, Wright K, Fex C, Le Saux N, Dales RE: Granulocyte inflammatory markers and airway infection during acute exacerbation of chronic obstructive pulmonary disease. American journal of respiratory and critical care medicine 200 I, 163:349-55.

92. Kang MJ, Choi JM, Kim BH, Lee CM, Cho WK, Choe G, Kim DH, Lee CG, Elias JA: IL-I8 induces emphysema and airway and 
vascular remodeling via IFN-gamma, IL-I 7A, and IL-I 3. American journal of respiratory and critical care medicine 2012, I 85: I 205-I7.

\section{FlOOOPrime
RECOMMENDED}

93. Kaur M, Smyth LJ, Cadden P, Grundy S, Ray D, Plumb J, Singh D: $T$ lymphocyte insensitivity to corticosteroids in chronic obstructive pulmonary disease. Respiratory research 2012, 13:20.

94. Moermans C, Heinen V, Nguyen M, Henket M, Sele J, Manise M, Corhay JL, Louis R: Local and systemic cellular inflammation and cytokine release in chronic obstructive pulmonary disease. Cytokine 201 I, 56:298-304.

95. Sapey E, Ahmad A, Bayley D, Newbold P, Snell N, Rugman P, Stockley RA: Imbalances between interleukin-I and tumor necrosis factor agonists and antagonists in stable COPD. J Clin Immunol 2009, 29:508-16.

96. Bucchioni E, Kharitonov SA, Allegra L, Barnes PJ: High levels of interleukin-6 in the exhaled breath condensate of patients with COPD. Respir Med 2003, 97:1299-302.

97. Di Stefano A, Capelli A, Donner CF: Role of interleukin-8 in the pathogenesis and treatment of COPD. Chest 2004, I 26:676-8.

98. Qiu Y, Zhu J, Bandi V, Atmar RL, Hattotuwa K, Guntupalli KK, Jeffery PK: Biopsy neutrophilia, neutrophil chemokine and receptor gene expression in severe exacerbations of chronic obstructive pulmonary disease. American journal of respiratory and critical care medicine 2003, I68:968-75.

99. Schulz C, Kratzel K, Wolf K, Schroll S, Kohler M, Pfeifer M: Activation of bronchial epithelial cells in smokers without airway obstruction and patients with COPD. Chest 2004, 125:1706-13.

100. Perng DW, Huang HY, Chen HM, Lee YC, Perng RP: Characteristics of airway inflammation and bronchodilator reversibility in COPD: a potential guide to treatment. Chest 2004, I 26:375-8I.

I0I. Damia Ade D, Gimeno JC, Ferrer MJ, Fabregas ML, Folch PA, Paya JM: A study of the effect of proinflammatory cytokines on the epithelial cells of smokers, with or without COPD. Archivos de bronconeumologia 2011, 47:447-53.

102. Beeh KM, Kornmann O, Buhl R, Culpitt SV, Giembycz MA, Barnes PJ: Neutrophil chemotactic activity of sputum from patients with COPD: role of interleukin 8 and leukotriene B4. Chest 2003, I 23: 1240-7.

103. Imaoka H, Hoshino T, Takei S, Kinoshita T, Okamoto M, Kawayama T, Kato S, Iwasaki H, Watanabe K, Aizawa H: Interleukin- 18 production and pulmonary function in COPD. Eur Respir J 2008, 31:287-97.

104. Freeman CM, Han MK, Martinez FJ, Murray S, Liu LX, Chensue SW, Polak T], Sonstein J, Todt JC, Ames TM, Arenberg DA, Meldrum CA, Getty C, McCloskey L, Curtis JL: Cytotoxic potential of lung CD8(+) $T$ cells increases with chronic obstructive pulmonary disease severity and with in vitro stimulation by IL-I 8 or IL-I 5. J Immunol 2010, I84:6504-13.

105. Calabrese F, Baraldo S, Bazzan E, Lunardi F, Rea F, Maestrelli P, Turato G, Lokar-Oliani K, Papi A, Zuin R, Sfriso P, Balestro E, Dinarello CA, Saetta M: IL-32, a novel proinflammatory cytokine in chronic obstructive pulmonary disease. American journal of respiratory and critical care medicine 2008, I 78:894-901.

106. Eustace A, Smyth LJ, Mitchell L, Williamson K, Plumb J, Singh D: Identification of cells expressing IL-I7A and IL-I7F in the lungs of patients with COPD. Chest 20II, I39:1089-100.

107. Chang Y, Nadigel J, Boulais N, Bourbeau J, Maltais F, Eidelman DH, Hamid Q: CD8 positive T cells express IL-I7 in patients with chronic obstructive pulmonary disease. Respiratory research $201 \mathrm{I}$, I2:43.

108. Vargas-Rojas MI, Ramirez-Venegas A, Limon-Camacho L, Ochoa L, Hernandez-Zenteno R, Sansores RH: Increase of ThI7 cells in peripheral blood of patients with chronic obstructive pulmonary disease. Respir Med 201 I, I05:1648-54.

109. Zhang $X$, Zheng H, Zhang H, Ma W, Wang F, Liu C, He S: Increased interleukin (IL)-8 and decreased IL-I7 production in chronic obstructive pulmonary disease (COPD) provoked by cigarette smoke. Cytokine 20I I, 56:717-25.

I I0. de Boer WI, van Schadewijk A, Sont JK, Sharma HS, Stolk J, Hiemstra PS, van Krieken JH: Transforming growth factor betal and recruitment of macrophages and mast cells in airways in chronic obstructive pulmonary disease. American journal of respiratory and critical care medicine 1998, I58:1951-7.

\section{FlOOOPrime
RECOMMENDED}

I II. Takizawa H, Tanaka M, Takami K, Ohtoshi T, Ito K, Satoh M, Okada Y, Yamasawa F, Nakahara K, Umeda A: Increased expression of transforming growth factor-betal in small airway epithelium from tobacco smokers and patients with chronic obstructive pulmonary disease (COPD). American journal of respiratory and critical care medicine 200I, I63:1476-83.

I 12. Kokturk N, Tatlicioglu T, Memis L, Akyurek N, Akyol G: Expression of transforming growth factor betal in bronchial biopsies in asthma and COPD. The Journal of asthma : official journal of the Association for the Care of Asthma 2003, 40:887-93.

I 13. Soltani A, Sohal SS, Reid D, Weston S, Wood-Baker R, Walters EH: Vessel-Associated Transforming Growth Factor-Betal (TGFbetal) Is Increased in the Bronchial Reticular Basement Membrane in COPD and Normal Smokers. PLoS One 2012, 7:e39736.

I 14. Baarsma HA, Spanjer Al, Haitsma G, Engelbertink LH, Meurs H, lonker MR, Timens W, Postma DS, Kerstjens HA, Gosens R: Activation of WNT/beta-catenin signaling in pulmonary fibroblasts by TGF-beta(I) is increased in chronic obstructive pulmonary disease. PLoS One 20I I, 6:e25450.

\section{FlOOOPrime
RECOMMENDED}

II5. Ichimaru Y, Krimmer DI, Burgess JK, Black JL, Oliver BG: TGFbeta enhances deposition of perlecan from COPD airway smooth muscle. American journal of physiology Lung cellular and molecular physiology 2012, 302:L325-33.

\section{FlOOOPrime}

\section{RECOMMENDED}

I 16. Steen VD, Medsger TA: Changes in causes of death in systemic sclerosis, 1972-2002. Ann Rheum Dis 2007, 66:940-4.

\section{FlOOOPrime}

RECOMMENDED

117. Ley B, Collard HR, King TE Jr: Clinical course and prediction of survival in idiopathic pulmonary fibrosis. American journal of respiratory and critical care medicine 20II, I 83:43 I-40.

I I8. Grieb G, Steffens G, Pallua N, Bernhagen J, Bucala R: Circulating fibrocytes-biology and mechanisms in wound healing and scar formation. Int Rev Cell Mol Biol 20I I, 29l:I-I9.

119. Strieter RM, Keeley EC, Hughes MA, Burdick MD, Mehrad B: The role of circulating mesenchymal progenitor cells (fibrocytes) in the pathogenesis of pulmonary fibrosis. J Leukoc Biol 2009, 86: | | ||-8.

120. Herzog EL, Bucala R: Fibrocytes in health and disease. Exp Hematol 2010, 38:548-56.

121. Tanjore H, Blackwell TS, Lawson WE: Emerging evidence for endoplasmic reticulum stress in the pathogenesis of idiopathic pulmonary fibrosis. American journal of physiology Lung cellular and molecular physiology 2012, 302:L72I-9.

\section{FlOOOPrime}

RECOMMENDED

122. King TE Jr., Pardo A, Selman M: Idiopathic pulmonary fibrosis. Lancet 20II, 378:1949-6I.

123. Willis BC, Liebler JM, Luby-Phelps K, Nicholson AG, Crandall ED, du Bois RM, Borok Z: Induction of epithelial-mesenchymal transition in alveolar epithelial cells by transforming growth factor-betal: potential role in idiopathic pulmonary fibrosis. Am J Pathol 2005, 166:1321-32.

\section{FlOOOPRIme
RECOMMENDED}

124. Homer RJ, Elias JA, Lee CG, Herzog E: Modern concepts on the role of inflammation in pulmonary fibrosis. Arch Pathol Lab Med 2011 , I35:780-8.

125. Bringardner $B D$, Baran $C P$, Eubank TD, Marsh $C B$ : The role of inflammation in the pathogenesis of idiopathic pulmonary fibrosis. Antioxid Redox Signal 2008, 10:287-301. 
126. Chambers RC: Procoagulant signalling mechanisms in lung inflammation and fibrosis: novel opportunities for pharmacological intervention? Br J Pharmacol 2008, I 53:S367-78.

127. Luzina IG, Todd NW, Nacu N, Lockatell V, Choi J, Hummers LK, Atamas SP: Regulation of pulmonary inflammation and fibrosis through expression of integrins alphaVbeta3 and alphaVbeta5 on pulmonary T lymphocytes. Arthritis Rheum 2009, 60:I530-9.

128. Mozaffarian A, Brewer AW, Trueblood ES, Luzina IG, Todd NW, Atamas SP, Arnett HA: Mechanisms of oncostatin M-induced pulmonary inflammation and fibrosis. J Immunol 2008, I 81:7243-53.

I29. Luzina IG, Todd NW, lacono AT, Atamas SP: Roles of T lymphocytes in pulmonary fibrosis. J Leukoc Biol 2008, 83:237-44.

130. Pochetuhen K, Luzina IG, Lockatell V, Choi J, Todd NW, Atamas SP: Complex regulation of pulmonary inflammation and fibrosis by CCLI 8. Am J Pathol 2007, I 7 I:428-37.

|3|. Kliment CR, Oury TD: Oxidative stress, extracellular matrix targets, and idiopathic pulmonary fibrosis. Free Radic Biol Med $2010,49: 707-17$

132. Kinnula VL, Fattman CL, Tan RJ, Oury TD: Oxidative stress in pulmonary fibrosis: a possible role for redox modulatory therapy. American journal of respiratory and critical care medicine 2005, 172:417-22.

133. Hecker L, Vittal R, Jones T, Jagirdar R, Luckhardt TR, Horowitz JC, Pennathur S, Martinez FJ, Thannickal VJ: NADPH oxidase-4 mediates myofibroblast activation and fibrogenic responses to lung injury. Nature medicine 2009, I 5:|077-8I.

\section{FlOOOPrime
RECOMMENDED}

134. Dancer RC, Wood AM, Thickett DR: Metalloproteinases in idiopathic pulmonary fibrosis. Eur Respir J 20I I, 38: |46 I-7.

135. Garcia-Alvarez J, Ramirez R, Sampieri CL, Nuttall RK, Edwards DR, Selman M, Pardo A: Membrane type-matrix metalloproteinases in idiopathic pulmonary fibrosis. Sarcoidosis Vasc Diffuse Lung Dis 2006, 23:|3-2|.

136. Tan RJ, Fattman CL, Niehouse LM, Tobolewski JM, Hanford LE, Li Q, Monzon FA, Parks WC, Oury TD: Matrix metalloproteinases promote inflammation and fibrosis in asbestos-induced lung injury in mice. American journal of respiratory cell and molecular biology 2006, 35:289-97.

137. Scotton CJ, Krupiczojc MA, Konigshoff M, Mercer PF, Lee YC, Kaminski N, Morser J, Post JM, Maher TM, Nicholson AG, Moffatt JD, Laurent GJ, Derian CK, Eickelberg O, Chambers RC: Increased local expression of coagulation factor $X$ contributes to the fibrotic response in human and murine lung injury. The Journal of clinical investigation 2009, I I 9:2550-63.

\section{FlOOOPrime
RECOMMENDED}

138. Mercer PF, Johns RH, Scotton CJ, Krupiczojc MA, Konigshoff M, Howell DC, McAnulty RJ, Das A, Thorley AJ, Tetley TD, Eickelberg O, Chambers RC: Pulmonary epithelium is a prominent source of proteinase-activated receptor-I-inducible CCL2 in pulmonary fibrosis. American journal of respiratory and critical care medicine 2009, | 79:4|4-25.

139. Bauman KA, Wettlaufer SH, Okunishi K, Vannella KM, Stoolman IS, Huang SK, Courey AJ, White ES, Hogaboam CM, Simon RH, Toews GB, Sisson TH, Moore BB, Peters-Golden M: The antifibrotic effects of plasminogen activation occur via prostaglandin E2 synthesis in humans and mice. The Journal of clinical investigation 2010, 120:1950-60.

140. Chambers RC, Laurent G]: Coagulation cascade proteases and tissue fibrosis. Biochem Soc Trans 2002, 30:194-200.

14I. Bogatkevich GS, Ludwicka-Bradley A, Nietert PJ, Akter T, van Ryn J, Silver RM: Antiinflammatory and antifibrotic effects of the oral direct thrombin inhibitor dabigatran etexilate in a murine model of interstitial lung disease. Arthritis Rheum 201I, 63:1416-25

142. Sime PJ, Xing Z, Graham FL, Csaky KG, Gauldie J: Adenovectormediated gene transfer of active transforming growth factorbetal induces prolonged severe fibrosis in rat lung. The Journal of clinical investigation 1997, 100:768-76.
143. Sheppard D: Transforming growth factor beta: a central modulator of pulmonary and airway inflammation and fibrosis. Proc Am Thorac Soc 2006, 3:4I 3-7.

144. Munger JS, Huang X, Kawakatsu H, Griffiths MJ, Dalton SL, Wu J, Pittet JF, Kaminski N, Garat C, Matthay MA, Rifkin DB, Sheppard D: The integrin alpha $v$ beta 6 binds and activates latent TGF beta I: a mechanism for regulating pulmonary inflammation and fibrosis. Cell 1999, 96:319-28.

\section{FlOOOPrime}

RECOMMENDED

145. Horan GS, Wood S, Ona V, Li DJ, Lukashev ME, Weinreb PH, Simon KJ, Hahm K, Allaire NE, Rinaldi NJ, Goyal J, Feghali-Bostwick CA, Matteson EL, O'Hara C, Lafyatis R, Davis GS, Huang X, Sheppard D, Violette SM: Partial inhibition of integrin alpha(v)beta6 prevents pulmonary fibrosis without exacerbating inflammation. American journal of respiratory and critical care medicine 2008, 177:56-65.

146. Sheppard D: Integrin-mediated activation of latent transforming growth factor beta. Cancer Metastasis Rev 2005, 24:395-402.

I47. Bonniaud P, Margetts PJ, Kolb M, Haberberger T, Kelly M, Robertson J, Gauldie J: Adenoviral gene transfer of connective tissue growth factor in the lung induces transient fibrosis. American journal of respiratory and critical care medicine 2003, 168:770-8.

148. Ponticos M, Holmes AM, Shi-wen X, Leoni P, Khan K, Rajkumar VS, Hoyles RK, Bou-Gharios G, Black CM, Denton CP, Abraham DJ, Leask A, Lindahl GE: Pivotal role of connective tissue growth factor in lung fibrosis: MAPK-dependent transcriptional activation of type I collagen. Arthritis Rheum 2009, 60:2I 42-55.

\section{FlOOOPrime
RECOMMENDED}

149. Atamas SP, Luzina IG, Dai H, Wilt SG, White B: Synergy between CD40 ligation and IL-4 on fibroblast proliferation involves IL-4 receptor signaling. J Immunol 2002, I 68: | | 39-45.

150. Jakubzick C, Choi ES, Joshi BH, Keane MP, Kunkel SL, Puri RK, Hogaboam CM: Therapeutic attenuation of pulmonary fibrosis via targeting of IL-4- and IL-I 3-responsive cells. J Immunol 2003, | 7 |:2684-93.

\section{FlOOOPrime \\ RECOMMENDED}

I5I. Jakubzick C, Kunkel SL, Puri RK, Hogaboam CM: Therapeutic targeting of IL-4- and IL-I3-responsive cells in pulmonary fibrosis. Immunol Res 2004, 30:339-49.

152. Doucet C, Brouty-Boye D, Pottin-Clemenceau C, Canonica GW, Jasmin C, Azzarone B: Interleukin (IL) 4 and IL-I3 act on human lung fibroblasts. Implication in asthma. The Journal of clinical investigation 1998, I01:2129-39.

153. Zhu Z, Homer RJ, Wang Z, Chen Q, Geba GP, Wang J, Zhang Y, Elias JA: Pulmonary expression of interleukin-13 causes inflammation, mucus hypersecretion, subepithelial fibrosis, physiologic abnormalities, and eotaxin production. The Journal of clinical investigation 1999, I03:779-88.

154. Lee CG, Homer RJ, Zhu Z, Lanone S, Wang X, Koteliansky V, Shipley JM, Gotwals P, Noble P, Chen Q, Senior RM, Elias JA: Interleukin- 13 induces tissue fibrosis by selectively stimulating and activating transforming growth factor beta(I). The Journal of experimental medicine 2001, 194:809-2I.

\section{FlOOOPrime
RECOMMENDED}

155. Sempowski GD, Derdak S, Phipps RP: Interleukin-4 and interferongamma discordantly regulate collagen biosynthesis by functionally distinct lung fibroblast subsets. I Cell Physiol 1996, I67: 290-6.

156. Jaffe HA, Gao Z, Mori Y, Li L, Varga J: Selective inhibition of collagen gene expression in fibroblasts by an interferongamma transgene. Exp Lung Res 1999, 25:199-2। 5 .

I57. Smith RE, Strieter RM, Zhang K, Phan SH, Standiford TJ, Lukacs NW, Kunkel SL: A role for C-C chemokines in fibrotic lung disease. J Leukoc Biol 1995, 57:782-7.

158. Gharaee-Kermani M, Denholm EM, Phan SH: Costimulation of fibroblast collagen and transforming growth factor betal gene expression by monocyte chemoattractant protein-I via specific receptors. J Biol Chem 1996, 271:17779-84. 
159. Moore BB, Paine R, 3rd, Christensen PJ, Moore TA, Sitterding S, Ngan R, Wilke CA, Kuziel WA, Toews GB: Protection from pulmonary fibrosis in the absence of CCR2 signaling. I Immunol 200I, 167:4368-77.

160. Moore BB, Kolodsick JE, Thannickal VJ, Cooke K, Moore TA, Hogaboam C, Wilke CA, Toews GB: CCR2-mediated recruitment of fibrocytes to the alveolar space after fibrotic injury. $\mathrm{Am} J$ Pathol 2005, 166:675-84.

161. Fritz DK, Kerr C, Fattouh R, Llop-Guevara A, Khan WI, Jordana M, Richards CD: A mouse model of airway disease: oncostatin M-induced pulmonary eosinophilia, goblet cell hyperplasia, and airway hyperresponsiveness are STAT6 dependent, and interstitial pulmonary fibrosis is STAT6 independent. I Immunol 201I, I86: I107-18.

162. Lo Re S, Lecocq M, Uwambayinema F, Yakoub Y, Delos M, Demoulin JB, Lucas S, Sparwasser T, Renauld JC, Lison D, Huaux F: Plateletderived growth factor-producing CD4+ Foxp3+ regulatory T lymphocytes promote lung fibrosis. American journal of respiratory and critical care medicine 20II, 184:1270-81.

163. Trojanowska M: Role of PDGF in fibrotic diseases and systemic sclerosis. Rheumatology (Oxford) 2008, 47:v2-4.

164. Abdollahi A, Li M, Ping G, Plathow C, Domhan S, Kiessling F, Lee LB, McMahon G, Grone HJ, Lipson KE, Huber PE: Inhibition of plateletderived growth factor signaling attenuates pulmonary fibrosis. The Journal of experimental medicine 2005, 20 I:925-35.

\section{FlOOOPrime
RECOMMENDED}

165. Luzina IG, Atamas SP, Wise R, Wigley FM, Xiao HQ, White B: Gene expression in bronchoalveolar lavage cells from scleroderma patients. American journal of respiratory cell and molecular biology 2002, 26:549-57.

166. Prasse A, Pechkovsky DV, Toews GB, Schafer M, Eggeling S, Ludwig C, Germann M, Kollert F, Zissel G, Muller-Quernheim J: CCLI 8 as an indicator of pulmonary fibrotic activity in idiopathic interstitial pneumonias and systemic sclerosis. Arthritis Rheum 2007, 56:1685-93

167. Pardo A, Smith KM, Abrams J, Coffman R, Bustos M, McClanahan TK, Grein J, Murphy EE, Zlotnik A, Selman M: CCLI 8/DC-CK-I/PARC up-regulation in hypersensitivity pneumonitis. J Leukoc Biol 2001, 70:610-6

168. de Nadai P, Charbonnier AS, Chenivesse C, Senechal S, Fournier $C$, Gilet J, Vorng H, Chang Y, Gosset P, Wallaert B, Tonnel AB, Lassalle P, Tsicopoulos A: Involvement of CCLI8 in allergic asthma. J Immunol 2006, 176:6286-93.

169. Mrazek F, Sekerova V, Drabek J, Kolek V, du Bois RM, Petrek M: Expression of the chemokine PARC mRNA in bronchoalveolar cells of patients with sarcoidosis. Immunol Lett 2002, 84: 17-22.

170. Prasse A, Pechkovsky DV, Toews GB, Jungraithmayr W, Kollert F, Goldmann T, Vollmer E, Muller-Quernheim J, Zissel G: A vicious circle of alveolar macrophages and fibroblasts perpetuates pulmonary fibrosis via CCLI 8. American journal of respiratory and critical care medicine 2006, I73:78I-92.

17I. Atamas SP, Luzina IG, Choi J, Tsymbalyuk N, Carbonetti NH, Singh IS, Trojanowska M, Jimenez SA, White B: Pulmonary and activationregulated chemokine stimulates collagen production in lung fibroblasts. American journal of respiratory cell and molecular biology 2003, 29:743-9.

172. Luzina IG, Highsmith K, Pochetuhen K, Nacu N, Rao JN, Atamas SP: PKCalpha mediates CCLI8-stimulated collagen production in pulmonary fibroblasts. American journal of respiratory cell and molecular biology 2006, 35:298-305.

173. Luzina IG, Tsymbalyuk N, Choi J, Hasday JD, Atamas SP: CCLI8stimulated upregulation of collagen production in lung fibroblasts requires SpI signaling and basal Smad3 activity. J Cell Physiol 2006, 206:22I-8.

174. Luzina IG, Papadimitriou JC, Anderson R, Pochetuhen K, Atamas SP: Induction of prolonged infiltration of $T$ lymphocytes and transient $\mathbf{T}$ lymphocyte-dependent collagen deposition in mouse lungs following adenoviral gene transfer of CCLI8. Arthritis Rheum 2006, 54:2643-55.
175. Hashimoto N, Jin H, Liu T, Chensue SW, Phan SH: Bone marrowderived progenitor cells in pulmonary fibrosis. The Journal of clinical investigation 2004, I | 3:243-52.

\section{FlOOOPrime}

RECOMMENDED

176. Phillips RJ, Burdick MD, Hong K, Lutz MA, Murray LA, Xue YY, Belperio JA, Keane MP, Strieter RM: Circulating fibrocytes traffic to the lungs in response to CXCLI 2 and mediate fibrosis. The Journal of clinical investigation 2004, I | 4:438-46.

\section{FlOOOPrime
RECOMMENDED}

177. Xu J, Mora A, Shim H, Stecenko A, Brigham KL, Rojas M: Role of the SDF-I/CXCR4 axis in the pathogenesis of lung injury and fibrosis. American journal of respiratory cell and molecular biology 2007, 37:291-9.

178. Wilson MS, Madala SK, Ramalingam TR, Gochuico BR, Rosas IO Cheever AW, Wynn TA: Bleomycin and IL-Ibeta-mediated pulmonary fibrosis is IL-I7A dependent. The Journal of experimental medicine 20I0, 207:535-52.

\section{FlOOOPrime}

\section{RECOMMENDED}

179. Lo ReS, Dumoutier L, Couillin I, Van Vyve C, Yakoub Y, Uwambayinema F, Marien B, van den Brule S, Van Snick J, Uyttenhove C, Ryffel B, Renauld JC, Lison D, Huaux F: IL-I7A-producing gammadelta T and ThI 7 lymphocytes mediate lung inflammation but not fibrosis in experimental silicosis. J Immunol 2010, 184:6367-77.

180. Mi S, Li Z, Yang HZ, Liu H, Wang JP, Ma YG, Wang XX, Liu HZ, Sun W, Hu ZW: Blocking IL-I7A promotes the resolution of pulmonary inflammation and fibrosis via TGF-betal-dependent and -independent mechanisms. J Immunol 20II, I87:3003-I4.

18I. Sun L, Louie MC, Vannella KM, Wilke CA, LeVine AM, Moore BB, Shanley TP: New concepts of IL-I0-induced lung fibrosis: fibrocyte recruitment and M2 activation in a CCL2/CCR2 axis. American journal of physiology Lung cellular and molecular physiology 20II, 300:L34I-53.

182. Garcia-Prieto E, Gonzalez-Lopez A, Cabrera S, Astudillo A, GutierrezFernandez A, Fanjul-Fernandez M, Batalla-Solis E, Puente XS, Fueyo A Lopez-Otin C, Albaiceta GM: Resistance to bleomycin-induced lung fibrosis in MMP-8 deficient mice is mediated by interleukin-10. PLoS One 2010, 5:el 3242.

183. Belperio JA, Dy M, Murray L, Burdick MD, Xue YY, Strieter RM, Keane MP: The role of the Th2 CC chemokine ligand CCLI 7 in pulmonary fibrosis. J Immunol 2004, I 73:4692-8.

184. Xing Z, Ohkawara Y, Jordana M, Graham F, Gauldie J: Transfer of granulocyte-macrophage colony-stimulating factor gene to rat lung induces eosinophilia, monocytosis, and fibrotic reactions. The Journal of clinical investigation 1996, 97: 1 102-10.

185. Xing Z, Tremblay GM, Sime PJ, Gauldie J: Overexpression of granulocyte-macrophage colony-stimulating factor induces pulmonary granulation tissue formation and fibrosis by induction of transforming growth factor-beta I and myofibroblast accumulation. Am J Pathol 1997, 150:59-66.

186. Moore BB, Coffey MJ, Christensen P, Sitterding S, Ngan R, Wilke CA McDonald R, Phare SM, Peters-Golden M, Paine R, 3rd, Toews GB GM-CSF regulates bleomycin-induced pulmonary fibrosis via a prostaglandin-dependent mechanism. J Immunol 2000, 165:4032-9.

187. Atamas SP, White B: The role of chemokines in the pathogenesis of scleroderma. Curr Opin Rheumatol 2003, 15:772-7.

188. Atamas SP, White B: Cytokine regulation of pulmonary fibrosis in scleroderma. Cytokine Growth Factor Rev 2003, 14:537-50.

189. Atamas SP: Complex cytokine regulation of tissue fibrosis. Life Sci 2002, 72:63I-43.

190. Haldar P, Brightling CE, Hargadon B, Gupta S, Monteiro W, Sousa A, Marshall RP, Bradding P, Green RH, Wardlaw AJ, Pavord ID: Mepolizumab and exacerbations of refractory eosinophilic asthma. The New England journal of medicine 2009, 360:973-84.

191. Wenzel S, Wilbraham D, Fuller R, Getz EB, Longphre M: Effect of an interleukin-4 variant on late phase asthmatic response to 
allergen challenge in asthmatic patients: results of two phase 2a studies. Lancet 2007, 370:|422-31.

\section{FlOOOPrime
RECOMMENDED}

192. Gauvreau GM, Boulet LP, Cockcroft DW, Fitzgerald JM, Carlsten C, Davis BE, Deschesnes F, Duong M, Durn BL, Howie KJ, Hui L, Kasaian MT, Killian KJ, Strinich TX, Watson RM, Y N, Zhou S, Raible D, O'Byrne PM: Effects of interleukin-I3 blockade on allergeninduced airway responses in mild atopic asthma. American journal of respiratory and critical care medicine 201 I, I83:I007-I4.

\section{FlOOOPrime
RECOMMENDED}

193. Maes T, Joos GF, Brusselle GG: Targeting interleukin-4 in asthma: lost in translation? American journal of respiratory cell and molecular biology 20I2, 47:26I-70.

194. Corren J: Anti-interleukin-5 antibody therapy in asthma and allergies. Curr Opin Allergy Clin Immunol 20 I I, I I:565-70.

\section{FlOOOPrime}

\section{RECOMMENDED}

195. Borish LC, Nelson HS, Lanz MJ, Claussen L, Whitmore JB, Agosti JM, Garrison L: Interleukin-4 receptor in moderate atopic asthma. A phase I/II randomized, placebo-controlled trial. American journal of respiratory and critical care medicine 1999, 160:1816-23.

196. Nair $P$, Pizzichini MM, Kjarsgaard $M$, Inman MD, Efthimiadis $A$, Pizzichini E, Hargreave FE, O'Byrne PM: Mepolizumab for prednisone-dependent asthma with sputum eosinophilia. The New England journal of medicine 2009, 360:985-93.

197. Abonia JP, Putnam PE: Mepolizumab in eosinophilic disorders. Expert review of clinical immunology 201 I, 7:4 II-7.

198. Berry MA, Parker D, Neale N, Woodman L, Morgan A, Monk P, Bradding P, Wardlaw AJ, Pavord ID, Brightling CE: Sputum and bronchial submucosal IL-I3 expression in asthma and eosinophilic bronchitis. The Journal of allergy and clinical immunology 2004, I | 4: I |06-9.

\section{FlOOPrime}

RECOMMENDED

199. Park SJ, Lee YC: Interleukin-I7 regulation: an attractive therapeutic approach for asthma. Respiratory research 20 I 0, I I:78.

\section{FlOOOPrime \\ RECOMMENDED}

200. Nkyimbeng-Takwi EH, Shanks K, Smith E, lyer A, Lipsky MM, Detolla LJ, Kikutani H, Keegan AD, Chapoval SP: Neuroimmune semaphorin 4A downregulates the severity of allergic response. Mucosal immunology 2012, 5:409-19.
20I. Smith EP, Shanks K, Lipsky MM, DeTolla LJ, Keegan AD, Chapoval SP: Expression of neuroimmune semaphorins 4A and $4 D$ and their receptors in the lung is enhanced by allergen and vascular endothelial growth factor. BMC immunology 201 I, I 2:30.

202. Erin EM, Leaker BR, Nicholson GC, Tan AJ, Green LM, Neighbour H, Zacharasiewicz AS, Turner J, Barnathan ES, Kon OM, Barnes PJ, Hansel TT: The effects of a monoclonal antibody directed against tumor necrosis factor-alpha in asthma. American journal of respiratory and critical care medicine 2006, I 74:753-62.

203. van der Vaart $H$, Koeter GH, Postma DS, Kauffman HF, ten Hacken $\mathrm{NH}$ : First study of infliximab treatment in patients with chronic obstructive pulmonary disease. American journal of respiratory and critical care medicine 2005, I72:465-9.

204. Rennard SI, Fogarty C, Kelsen S, Long W, Ramsdell J, Allison J, Mahler D, Saadeh C, Siler T, Snell P, Korenblat P, Smith W, Kaye M, Mandel M, Andrews C, Prabhu R, Donohue JF, Watt R, Lo KH, Schlenker-Herceg R, Barnathan ES, Murray J; COPD Investigators: The safety and efficacy of infliximab in moderate to severe chronic obstructive pulmonary disease. American journal of respiratory and critical care medicine 2007, 175:926-34.

\section{FlOOOPrime
RECOMMENDED}

205. Barnes PJ: Unexpected failure of anti-tumor necrosis factor therapy in chronic obstructive pulmonary disease. American journal of respiratory and critical care medicine 2007, I 75:866-7.

206. Barnes PJ: The cytokine network in chronic obstructive pulmonary disease. American journal of respiratory cell and molecular biology 2009, 4I:631-8.

207. Ferrara N, Gerber HP, LeCouter J: The biology of VEGF and its receptors. Nature medicine 2003, 9:669-76.

208. Crawford Y, Ferrara N: VEGF inhibition: insights from preclinical and clinical studies. Cell and tissue research 2009, 335:26I-9.

209. Barnes PJ: The cytokine network in asthma and chronic obstructive pulmonary disease. The Journal of clinical investigation 2008, I | 8:3546-56.

210. Wenzel S, Holgate ST: The mouse trap: It still yields few answers in asthma. American journal of respiratory and critical care medicine 2006, 174: I |73-6 discussion I I76-8.

2II. Mestas J, Hughes CC: Of mice and not men: differences between mouse and human immunology. J Immunol 2004, I 72:273 I-8.

212. Finkelman FD, Wills-Karp M: Usefulness and optimization of mouse models of allergic airway disease. The Journal of allergy and clinical immunology 2008, 121:603-6. 